\title{
Genotypic characterization and safety assessment of lactic acid bacteria from indigenous African fermented food products
}

David B Adimpong ${ }^{1,2^{*}}$, Dennis S Nielsen ${ }^{1}$, Kim I Sørensen², Patrick MF Derkx² and Lene Jespersen ${ }^{1}$

\begin{abstract}
Background: Indigenous fermented food products play an essential role in the diet of millions of Africans. Lactic acid bacteria (LAB) are among the predominant microbial species in African indigenous fermented food products and are used for different applications in the food and biotechnology industries. Numerous studies have described antimicrobial susceptibility profiles of $L A B$ from different parts of the world. However, there is limited information on antimicrobial resistance profiles of LAB from Africa. The aim of this study was to characterize 33 LAB previously isolated from three different African indigenous fermented food products using (GTG) ${ }_{5}$-based rep-PCR, sequencing of the $16 \mathrm{~S}$ rRNA gene and species-specific PCR techniques for differentiation of closely related species and further evaluate their antibiotic resistance profiles by the broth microdilution method and their haemolytic activity on sheep blood agar plates as indicators of safety traits among these bacteria.

Results: Using molecular biology based methods and selected phenotypic tests such as catalase reaction, $\mathrm{CO}_{2}$ production from glucose, colonies and cells morphology, the isolates were identified as Lactobacillus delbrueckii, Lactobacillus fermentum, Lactobacillus ghanensis, Lactobacillus plantarum, Lactobacillus salivarius, Leuconostoc pseudomesenteroides, Pediococcus acidilactici, Pediococcus pentosaceus and Weissella confusa. The bacteria were susceptible to ampicillin, chloramphenicol, clindamycin and erythromycin but resistant to vancomycin, kanamycin and streptomycin. Variable sensitivity profiles to tetracycline and gentamicin was observed among the isolates with Lb. plantarum, Lb. salivarius, W. confusa (except strain SK9-5) and Lb. fermentum strains being susceptible to tetracycline whereas Pediococcus strains and $L b$. ghanensis strains were resistant. For gentamicin, Leuc. pseudomesenteroides, $L b$. ghanensis and Ped. acidilactici strains were resistant to $64 \mathrm{mg} / \mathrm{L}$ whereas some $W$. confusa and $L b$. plantarum strains had a MIC value of $16 \mathrm{mg} / L$ and $32 \mathrm{mg} / L$ respectively. No $\beta$-haemolytic activity was observed, however, a-haemolytic activity was observed in $27 \%$ (9) of the strains comprising Lb. salivarius (6), W. confusa (2) and Lb. delbrueckii (1) isolates.
\end{abstract}

Conclusions: The resistance to kanamycin and vancomycin is probably an intrinsic feature since similar observations were reported in the literature for LAB. Low prevalence of pathogenicity indicator traits were observed among the isolates especially with the presence of poor haemolytic activities and they could therefore be considered as interesting candidates for selection of starter cultures or probiotics for different applications.

\footnotetext{
* Correspondence: dadimpong@life.ku.dk

${ }^{1}$ Department of Food Science, University of Copenhagen, Faculty of Life

Sciences, Rolighedsvej 30, DK-1958, Frederiksberg C, Denmark

${ }^{2}$ Chr-Hansen A/S, 10-12 Bøge Allé, DK-2970 Hørsholm, Denmark
} 


\section{Background}

Fermented food products have a long history and form significant part of the diet of many indigenous communities in the developing world [1-3]. African indigenous fermented food products, like many fermented food products in different parts of the world are deemed to have improved flavour, texture, increased shelf-life, bioavailability of micronutrients, and reduced or absence of antinutrition and toxic compounds among others [4-7]. Previous works on African fermented foods have revealed a complex and significant microbial biodiversity responsible for these inherent desirable characteristics [6,8-12] and Lactobacillus, Leuconostoc and to a lesser extent Pediococcus, Lactococcus and Weissella species are the most predominant LAB genera $[4,13]$.

Some of these foods include; lafun, kenkey, koko, dawadawa/soumbala, nyarmie, garis, agbelima and pito/ dolo [9,11,14-17]. Koko is a thick porridge which is made from millet, corn or sorghum and is consumed in many communities in Ghana. According to Lei and Jacobsen [4], the predominant microbial species in koko sour water (KSW) obtained from millet were W. confusa, $L b$. fermentum, Lb. salivarius and Pediococcus spp. Pito is also a fermented alcoholic beverage which is popular but in different variants among many indigenous communities in sub-Sahara African countries such as Burkina Faso, Ghana, Togo, Nigeria, and Benin among others. It is produced from malted sorghum or maize and sometimes a combination of both. The production process involves milling of malted sorghum, mashing, acidification, cooking, cooling, and alcoholic fermentation of the wort by the back-sloping process which involves using yeasts from previously fermented product $[9,18]$. It is therefore a spontaneous mixed fermentation product in which the predominant microbial floras are yeasts and LAB. Lb. fermentum, Lb. delbrueckii and Pediococcus species are the predominant LAB species $[9,18]$. Cocoa is arguably the most significant cash crop in many tropical countries such as Ivory Coast and Ghana. Raw cocoa beans are embedded in mucilaginous pulp and characterized by an astringent and unpleasant taste and flavour. To obtain the characteristics cocoa flavour, the mucilaginous cocoa pulp has to be fermented, dried and then roasted [8]. Cocoa fermentation is therefore the main stage in cocoa post-harvest processing [19] and contributes significantly to the characteristics final flavour of chocolates. There is microbial succession in the natural or spontaneous fermentation process of cocoa with LAB being among the dominant microbial species $[8,19]$.

$L A B$ are very significant in the dairy and biotechnology industries. They are used as starter cultures for dairy fermented food products, human and animal health products and animals feed inoculants. They have been classified as 'generally recognized as safe' (GRAS) due to their general occurrence in many fermented and nonfermented food products and also being part of the human commensal micro-flora. There have however been a few reported cases on clinical infections such as endocarditis, bacteraemia, and urinary tract infections caused by these microbial species, though in all these cases, patients had underlying conditions which predisposed them to infections particularly in the case of endocarditis [20,21]. Lactobacillus rhamnosus, Lactococcus lactis, Leuconostoc species and Lactobacillus casei (paracasei) have been cited in some non-enterococcal LAB endocarditis cases [20]. In view of this, it is relevant to have a more thorough safety assessment of LAB before their uses as live cultures for varying applications in the food and feed industry.

Moreover, the wide spread use of antibiotics in human medicines and farm practices has over the past century led to the spread of antibiotic resistant microorganisms. Antibiotics efficacy on bacteria is defined in terms of their MIC $(\mathrm{mg} / \mathrm{L})$ value which is considered as the reference point for comparing different antibiotics potency [22]. It has been shown that genes coding for antibiotics resistance can be transferred among bacteria of different genera and thus to pathogenic bacteria which consequently cannot be treated with previously successful antibiotics [23]. In a study by Temmerman et al. [24], it was observed that out of a total of 268 bacteria isolated from 55 European probiotics products, antibiotic resistance among 187 of the isolates was detected against kanamycin (79\% of the isolates), vancomycin (65\%), tetracycline (26\%), penicillin G (23\%), erythromycin (16\%) and chloramphenicol (11\%) whereas $68.4 \%$ of the isolates showed resistance against multiple antibiotics including intrinsic resistances. According to Kastner et al. [25], out of 200 starter cultures and probiotic bacteria isolated from 90 different food sources in Zurich, 27 isolates exhibited resistance patterns that could not be ascribed as an intrinsic feature of the respective genera. Ninety four tetracycline-resistant LAB strains from fermented dry sausages were also reported by Gevers et al. [26] in which it was attributed to the presence of tetracycline resistance tet $(\mathrm{M})$ gene.

While many studies have investigated the resistance profiles of LAB from the European origin [27-29], much less have been reported on the antimicrobial susceptibility of $\mathrm{LAB}$ of African origin. In some developing countries for instance, there is influx of antibiotics from different parts of the world into the market and subsequently, stricter regulations and laws are not enforced to regulate antibiotics uses as human medicine [30,31]. Antibiotics could even be purchased from local pharmacies as over-the-counter preparations, without prescriptions [32]. In Ghana, clinical isolates 
with multiple drug resistance to the four predominantly used antibiotic drugs; ampicillin, cotrimozaxole, tetracycline and chloramphenicol have been reported [33]. Ouoba et al. [34] also observed that probiotic LAB and bifidobacteria of African and European origin were resistant to vancomycin, tetracycline, kanamycin, sulphamethoxazole, neomycin, nalidixan, apramycin and colistin. Thus the potential health risks that could result from the transfer of antibiotic resistance genes from $L A B$ reservoir strains to bacteria in the resident microflora of the human gastrointestinal tract or pathogenic bacteria cannot be overlooked especially if the strains are to be introduced as live culture in food or feed products. To prevent the spread of antibiotics resistant genes, an application for European Food Safety Authority (EFSA) approval of microorganisms as feed additives or plant protection agents for instance, requires mandatory information on frequently used drugs resistant profiles of the bacteria [35]. Inter-genus and inter-species differences exist in antimicrobial susceptibility of bacteria as it has been indicated in some studies $[29,34]$. Genotyping of microbial species and their safety evaluations are hence essential in the microbiological risk assessment process prior to further study of these bacteria for different applications in the food and feed industry.

The aim of the present study was to genotypically characterise $33 \mathrm{LAB}$ isolated from African indigenous fermented food products and further evaluate their safety characteristics in terms of resistance to relevant antibiotics and haemolytic activities in order to increase our at present limited knowledge on antibiotic resistance profiles of LAB from African indigenous fermented food products.

\section{Methods}

Bacterial strains, cultivation conditions and preliminary phenotypic characterizations

The lactic acid bacteria strains used in this study were obtained from three different African indigenous fermented foods (Table 1). Stock-cultures were maintained in MRS broth (Oxoid Ltd., CM0359, pH 6.2 \pm 0.2 , Basingstoke, Hempshire, England) supplemented with $20 \%$ glycerol and stored at $-80^{\circ} \mathrm{C}$. Working cultures were made by inoculating $10 \mathrm{ml}$ MRS broth with freeze-stock culture and then incubated at $37^{\circ} \mathrm{C}$ overnight in a standard incubator without agitation. The isolates were characterized by colony morphology and cells morphology using phase-contrast microscopy, $\mathrm{CO}_{2}$ production from glucose in MRS broth with Durham tubes and catalase reaction with $3 \% \mathrm{H}_{2} \mathrm{O}_{2}$.

\section{Genotypic characterization}

Genomic DNA preparation for PCR and sequencing

\section{reactions}

Overnight-culture of each strain was streak-plated on MRS agar (Oxoid Ltd., CM0361, pH 6.2 \pm 0.2 , Basingstoke, Hempshire, England) and incubated at $37^{\circ} \mathrm{C}$ under anaerobic conditions (AnaeroGen, Oxoid) for $48 \mathrm{hrs}$. Genomic DNA was extracted from a single colony of each strain using the InstaGene Matrix DNA extraction

Table 1 Sources of isolation of 33 lactic acid bacteria investigated in this study

\begin{tabular}{|c|c|c|c|}
\hline Species and strains & Source of isolation & Raw materials used & Reference \\
\hline $\begin{array}{l}\text { Lb. plantarum } \\
\text { L106, L547, L544, L415, } \\
\text { L263, L260, L142, LA113 }\end{array}$ & Fermenting cocoa beans (FCB) & Cocoa pulp ${ }^{a}$ & {$[8]$} \\
\hline $\begin{array}{l}\text { Lb. plantarum } \\
\mathrm{S} 1, \mathrm{~S} 2\end{array}$ & Koko sour water (KSW) & Sorghum, maize, millet ${ }^{b}$ & {$[14]$} \\
\hline $\begin{array}{l}\text { Lb. ghanensis } \\
\text { L489, L499 }\end{array}$ & FCB & a & {$[8]$} \\
\hline $\begin{array}{l}\text { Leuc. pseudomesenteroides } \\
\text { L8 }\end{array}$ & FCB & $\mathrm{a}$ & {$[8]$} \\
\hline $\begin{array}{l}\text { Lb. fermentum } \\
\text { ZN7b-2, ZN7b-7 }\end{array}$ & Dolo and pito wort (DPW) & Sorghum, maize ${ }^{c}$ & {$[9]$} \\
\hline $\begin{array}{l}\text { Lb. delbrueckii species } \\
\text { ZN7a-9 }\end{array}$ & DPW & $C$ & {$[9]$} \\
\hline $\begin{array}{l}\text { Lb. salivarius } \\
\text { FK10-10, FK11-2, FK11-4, } \\
\text { FK11-8, FK11-9 }\end{array}$ & KSW & $b$ & {$[14]$} \\
\hline $\begin{array}{l}\text { Ped. acidilactici } \\
\text { N8, N9, N10 }\end{array}$ & KSW & $b$ & {$[14]$} \\
\hline $\begin{array}{l}\text { Ped. pentosaceus } \\
\text { P4, P5, S4 }\end{array}$ & KSW & $b$ & {$[14]$} \\
\hline $\begin{array}{l}\text { W. confusa } \\
\text { P2, P3, SK9-2, SK9-5, } \\
\text { SK9-7, FK10-9 }\end{array}$ & KSW & $b$ & {$[14]$} \\
\hline
\end{tabular}


kit (Bio-Rad, Hecules, CA, USA) and following the manufacturer's instructions. DNA was stored at $-20^{\circ} \mathrm{C}$ and used for all PCR reactions mentioned in this study.

\section{Rep-PCR}

Genomic DNA was analysed with the rep-PCR fingerprinting method using the GTG $_{5}$ (5'-GTG GTG GTG GTG GTG-3') primer (DNA Technology A/S, Denmark) with the protocol of Nielsen et al. [21]. Electrophoresis conditions and image analysis with the Bionumerics software package (Applied Maths, Sint-Martens-Latem, Belgium) were performed as previously [8].

\section{S rRNA gene sequencing}

PCR amplification of 16S rRNA gene of all the isolates was performed with the primers $7 \mathrm{f}$ (5'-AGA GTT TGA TYM TGG CTC AG-3') and 1510r (5'-ACG GYT ACC TTG TTA CGA CTT-3') [36] (DNA Technology A/S, Denmark). The reaction mixture consisted; $5.0 \mu \mathrm{l}$ of $10 \mathrm{X}$ PCR reaction buffer (Fermentas, Germany), $0.2 \mathrm{mM}$ dNTP-mix (Fermentas, Germany), $1.5 \mathrm{mM} \mathrm{MgCl} 2,0.1$ $\mathrm{pmol} / \mu \mathrm{l}$ primers $7 \mathrm{f}$ and $1510 \mathrm{r}, 0.5 \mu \mathrm{l}$ formamide (Merck), $0.50 \mu \mathrm{l}$ of $1 \mathrm{mg} / \mathrm{ml}$ bovine serum albumin (New England Biolabs), $0.25 \mu \mathrm{l}$ DreamTaq DNA polymerase $(5 \mathrm{u} / \mu \mathrm{l})$ (Fermentas, Germany) and $1.5 \mu \mathrm{l}$ of the extracted genomic DNA. The volume of the PCR mixture was adjusted to $50 \mu \mathrm{l}$ with sterile MilliQ water. PCR amplification was performed in DNA thermocycler (Gene Amp PCR System 2400, Perkin-Elmer) at the following thermocycling conditions; $5 \mathrm{~min}$ of initial denaturation at $94^{\circ}$ $\mathrm{C}$, followed by 30 cycles of $94^{\circ} \mathrm{C}$ for 90 seconds, $52^{\circ} \mathrm{C}$ for 30 seconds, $72^{\circ} \mathrm{C}$ for 90 seconds and a final elongation step of $72^{\circ} \mathrm{C}$ for 7 minutes. To check for successful PCR amplification, $10 \mu \mathrm{l}$ of the PCR product was electrophoresed in a $2 \%$ agarose gel in $1 \mathrm{X}$ TBE $(1 \mathrm{hr}, 100 \mathrm{~V})$. PCR products were purified of DNA amplification reagents using NucleoSpin ${ }^{\circledR}$ DNA purification kit by following the manufacturer's instructions. Sequencing was performed in both directions with the universal primers 27f (5'AGA GTT TGA TCM TGG CTC AG-3') and 1492r (5'TAC GGY TAC CTT GTT ACG ACT T-3') by a commercial sequencing facility (Macrogen Inc., Korea). The sequences were corrected using Chromas version 2.33 (Technelysium Pty Ltd). Corrected sequences were aligned to 16S rRNA gene sequences in the GenBank data base using the BLAST algorithm [37].

\section{Differentiation of Lactobacillus plantarum, $L b$.} paraplantarum and $L b$. pentosus by multiplex $P C R$ using recA gene-based primers

A multiplex PCR assay for differentiation of $L b$. plantarum, $L b$. paraplantarum and $L b$. pentosus was performed as described by Torriani et al. [38]. Genomic DNA from $L b$. paraplantarum LTH5200, Lb. pentosus
DSM20314 ${ }^{\mathrm{T}}$ and $L b$. plantarum DSM20174 ${ }^{\mathrm{T}}$ were used as positive control and genomic DNA from Leuconostoc pseudomesenteroides L8 and Lb. ghanensis L499 were used as negative control.

\section{Differentiation of Weissella confusa and W. cibaria strains}

The closely related species $W$. confusa and W. cibaria were differentiated from each other by a $W$. confusa species-specific PCR method as described by Fusco et al. [39]. Genomic DNA from W. confusa LMG $11983^{\mathrm{T}}$ was used as positive control. Genomic DNA from the following species was used as negative control; W. cibaria $17699^{\mathrm{T}}$, Pediococcus acidilactici DSM20284 ${ }^{\mathrm{T}}$, Ped. pentosaceus DSM20336 ${ }^{\mathrm{T}}$, Lb. fermentum DSM20052 ${ }^{\mathrm{T}}$, Lb. pentosus DSM20314 ${ }^{\mathrm{T}}$, Lb. paraplantarum LTH5200, Lb. delbrueckii subsp. lactis DSM20073, and Lb. delbrueckii subsp. bulgaricus DSM20080.

\section{Safety characterizations}

Antibiotics MIC testing by the broth microdilution method

Nine antibiotics were included in the assay: ampicillin and vancomycin as inhibitors of cell wall synthesis, clindamycin, chloramphenicol, erythromycin, gentamicin, kanamycin, streptomycin and tetracycline as inhibitors of protein synthesis. All antibiotics were obtained from Sigma (St. Louis, Mo., USA) in powdered form and $2 \mathrm{~g} / \mathrm{L}$ stock solutions prepared. Chloramphenicol and erythromycin stock solutions were prepared in 95\% ethanol and the remaining antibiotics stock solutions prepared in sterile MilliQ water and filter sterilized (MILLEX GP Syringe Driven Filter Unit, $0.22 \mu \mathrm{m}$, Millipore, Ireland). Aliquots $(1 \mathrm{ml})$ of the stock solutions were stored at $-20^{\circ} \mathrm{C}$. The minimum inhibitory concentration of antibiotics (MICs, mg/L) for all bacteria (except Lb. ghanensis L489 and Lb. delbrueckii $\mathrm{ZN9}_{\mathrm{a}}-7$ ) was determined by a modification of the broth micro-dilution method reported by Mayrhofer et al. [40] and Domig et al. [41] with different antibiotics concentration ranges depending on the particular antibiotic. In summary of the method, antibiotics stock solution $(2.0 \mathrm{~g} / \mathrm{L})$ was added to MRS broth ( $\mathrm{pH}$ 6.2) and then followed by $\log _{2}$ serial dilutions to obtain the appropriate antibiotics concentrations. The media $(198 \mu \mathrm{l})$ with the appropriate antibiotic concentration was then dispensed into wells of sterile commercial flat-bottom microtitre plates with lids (Fisher Scientific, Biotech Line A/S, Denmark) and stored at $-20^{\circ} \mathrm{C}$ for overnight. Prior to inoculation, the plates were allowed to attain room temperature. Inocula were prepared by suspending single isolated colonies of bacteria (MRSagar, $37^{\circ} \mathrm{C}, 48 \mathrm{hrs}$ ) in $3 \mathrm{ml}$ sterile $0.9 \% \mathrm{NaCl}$. Turbidity of the cells suspension was adjusted to $1 \mathrm{McFarland}$ standard equivalent (approx. $3 \times 10^{8} \mathrm{cfu} / \mathrm{ml}$ ). The plates were inoculated with $2 \mu \mathrm{l}$ of the cell suspension to obtain approximately $3 \times 10^{6} \mathrm{cfu} / \mathrm{ml}$ in each well. Plates were 
incubated under anaerobic conditions at $37^{\circ} \mathrm{C}$ for $24 \mathrm{hrs}$ (COY Laboratory Products INC, USA). All MIC testing was performed in duplicates and with one antibiotic free well inoculated and an un-inoculated well containing test media as negative control. The MIC was defined as the lowest concentration of antibiotic giving a complete inhibition of visible growth in comparison with inoculated and un-inoculated antibiotic-free wells.

\section{Haemolysis test}

The bacteria were tested for haemolysis on tryptone soy agar with sheep blood (TSA-SB) (Oxoid Ltd, PB5012A, $\mathrm{pH} 7.5 \pm 0.2$, Wesel, Germany) by streaking $24 \mathrm{hr}$ cultures on the blood agar plates followed by incubation at $37^{\circ} \mathrm{C}$ under anaerobic conditions (Anaerogen, Oxoid) for 24 hrs. The appearance of clear zones around the bacteria colonies indicated the presence of $\beta$-haemolysis whereas green zones around the colonies suggested $\alpha$ haemolysis [42].

\section{Nucleotide accession numbers}

The nucleotide sequences determined in this study have been assigned GenBank Accession Nos. JQ801703JQ801728.

\section{Results}

\section{Genotypic characterization}

The LAB included in the study (Table 1) were isolated from three different African indigenous fermented food products. To confirm their identities, selected phenotypic tests such as catalase reaction, $\mathrm{CO}_{2}$ production from glucose, colony and cell morphology along with genotypic identification methods were performed. Initially all 33 strains were subjected to rep-PCR (GTG) fingerprinting technique for genotypic grouping. Numerical analysis of the (GTG) $)_{5}$ PCR fingerprint band patterns obtained is shown in Figure 1.

Sequencing of $16 \mathrm{~S}$ rRNA gene of all the isolates was performed to further confirm the identities of the strains within each cluster. A BLAST search of the $16 \mathrm{~S}$ rRNA gene sequences obtained was then performed at NCBI revealing high similarity values to a number of sequences in the GenBank database. Strains identified as W. confusa/cibaria showed 99\% 16S rRNA sequence homology to both W. confusa and W. cibaria species in the GenBank database. These strains were further subjected to species-specific PCR in order to confirm their true identity. Strains S1 and S2 were previously identified as $L b$. paraplantarum based on intergenic transcribed spacers PCR restriction fragment length polymorphism (ITSPCR/RFLP) grouping, 16S rRNA sequencing and pulsedfield gel electrophoresis (REA-PFGE) [14] and form one cluster group further away from the $L b$. plantarum group as shown in the numerical analysis of the $(\mathrm{GTG})_{5^{-}}$
PCR band patterns in Figure 1. However, re-sequencing of the 16S rRNA gene indicated that strains S1 and S2 have high level of sequence homology to both $L b$. paraplantarum and Lb. plantarum. A multiplex PCR assay using species-specific primers targeting the recA gene was used to achieve unambiguous identification of all strains belonging to the $L b$. plantarum-group by $16 \mathrm{~S}$ rRNA gene sequencing (Figure 2). All these strains including strains S1 and S2 produced a PCR product of size 318 bp similar to the Lb. plantarum DSM20174 ${ }^{\mathrm{T}}$ positive control strain and were consequently confirmed to be $L b$. plantarum strains.

Also, using the $W$. confusa species-specific PCR technique reported by Fusco et al. [39], PCR amplified products were obtained for all the strains with high 16S rRNA gene similarity to both $W$. confusa and $W$. cibaria as shown in Figure 3. The size of the amplicon (225 bp) obtained for each of the strains was similar to that obtained for W. confusa LMG $11983^{\mathrm{T}}$ which was used as reference strain. This therefore confirms that the strains; P2, P3, SK9-2, SK9-5, SK9-7 and FK10-9 were $W$. confusa strains. In the previous study [9], strains ZN7a-9, ZN7b-2 and ZN7b-7 were identified as $L b$. delbrueckii strains based on ITSPCR/RFLP analysis and PFGE-Asc I fingerprint patterns. However, a BLAST search of the sequences of ZN7b-2 and ZN7b-7 in the GenBank database gave high identity values for $L b$. fermentum strains. As also shown in the dendrogram of the rep-PCR fingerprint band patterns, these two strains also formed one cluster which was separated from ZN7a-9 which sequence has high similarity value to $L b$. delbrueckii sequences in the Genbank database. Thus ZN7b-2 and ZN7b-7 were re-identified as $L b$. fermentum strains.

\section{Antibiotic susceptibility testing}

The results of antibiotic susceptibility testing are shown in Table 2. The bacteria were considered resistant to a particular antibiotic when the MIC (mg/L) values obtained were higher than the recommended breakpoint value defined at species level by the FEEDAP Panel; Panel on Additives and Products or Substances used in Animal Feed [22]. All strains were resistant to kanamycin (MIC range $8-128 \mathrm{mg} / \mathrm{L}$ ), streptomycin (64-128 $\mathrm{mg} / \mathrm{L}$ ) and vancomycin (MIC range $0.5-8.0 \mathrm{mg} / \mathrm{L}$ ) within the $\mathrm{MIC}$ ranges assayed (Table 2). The strains were highly susceptible to ampicillin (0.5-2.0 mg/L), chloramphenicol (2-4 mg/L), clindamycin (0.5-2.0 $\mathrm{mg} / \mathrm{L})$ and erythromycin (0.5$1.0 \mathrm{mg} / \mathrm{L})$. The chloramphenicol MIC value (4 mg/L) obtained for Lb. plantarum, Leuc. pseudomesenteroides, Lb. ghanensis and Lb. fermentum was one-fold higher than the MIC value obtained for Ped. acidilactici, Ped. pentosaceus and Weissella species. Lb. 


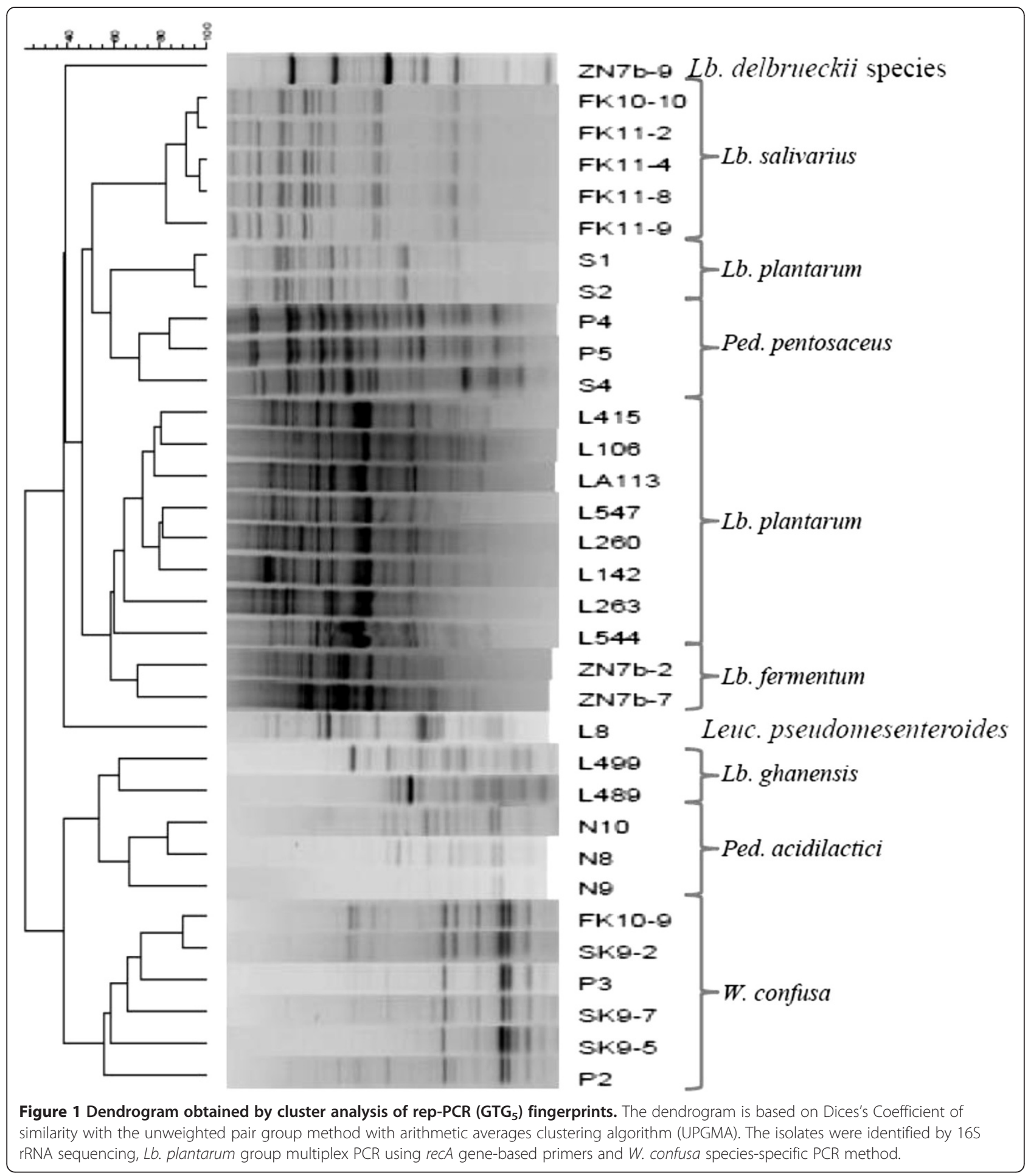

plantarum, Lb. salivarius, $W$. confusa (except strain SK9-5) and Lb. fermentum strains were susceptible to tetracycline. However, Pediococcus strains and the $L b$. ghanensis strain were resistant to tetracycline since the MIC values (16-32 $\mathrm{mg} / \mathrm{L})$ obtained were higher than the recommended breakpoint value $(8 \mathrm{mg} / \mathrm{L})$. The resistance profile of the strains to gentamicin varies at both species and strains level. Leuc. pseudomesenteroides, Lb. ghanensis and Ped. acidilactici strains were resistant to $64 \mathrm{mg} / \mathrm{L}$ gentamicin. However, the majority (4 out of 5 ) of $W$. confusa strains have MIC value of $16 \mathrm{mg} / \mathrm{L}$ whereas the MIC value obtained for most (7 strains) of Lb. plantarum strains was $32 \mathrm{mg} / \mathrm{L}$. 


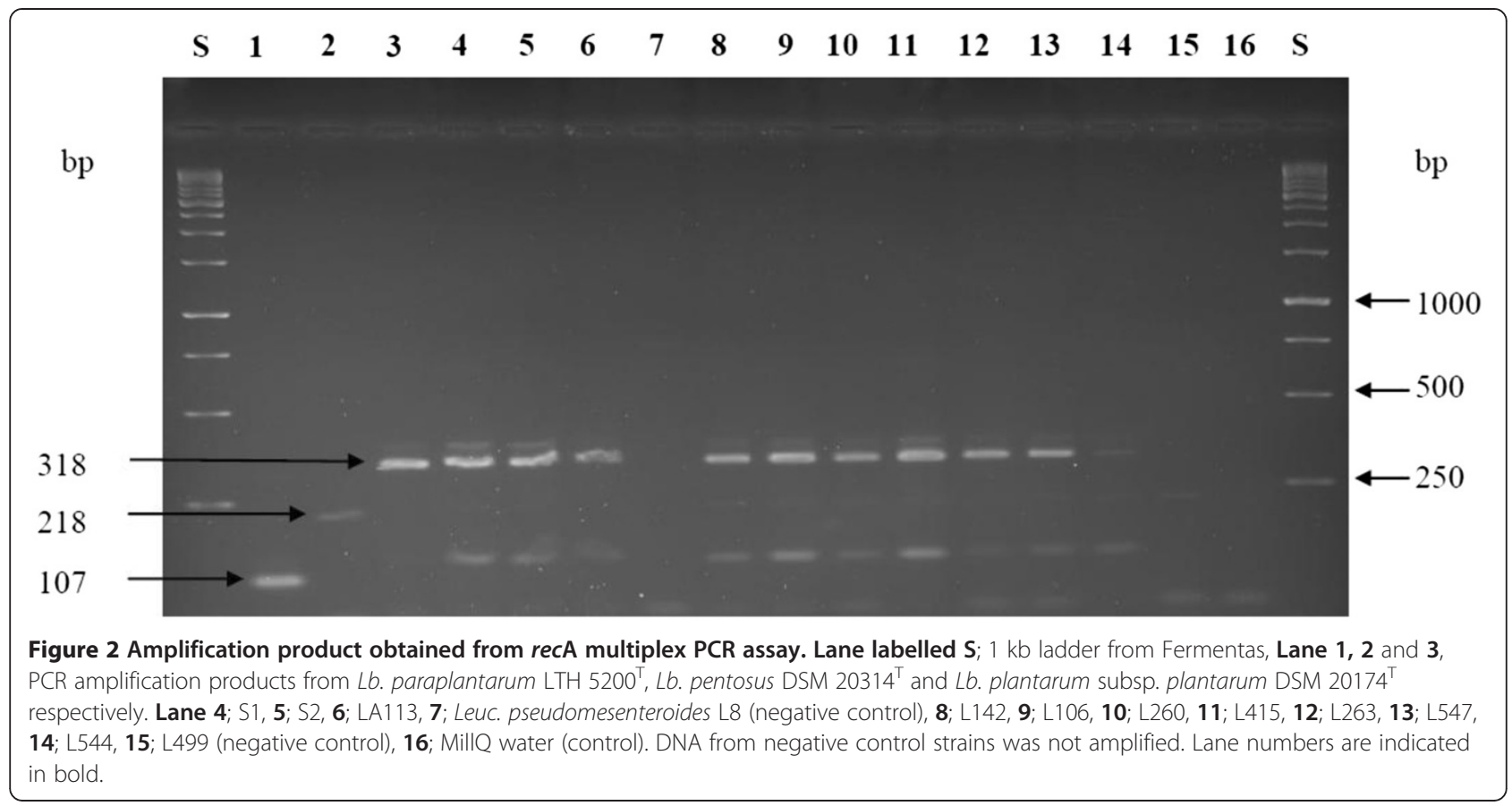

\section{Haemolysis testing}

After streaking the bacteria on tryptone soy agar with sheep blood, no $\beta$-haemolysis was observed in any of the bacteria strains. However, as shown in Figure 4, $\alpha$-haemolysis was observed in 9 out of the 33 strains of which 6 strains were Lb. salivarius, 2 strains $W$. confusa and the Lb. delbrueckii species strain.

\section{Discussion}

The reproducibility and discriminatory power of rep-PCR $(\mathrm{GTG})_{5}$ in typing at species and subspecies level have previously been reported [8,43-45] and also in the present study the technique proved useful for genotypic fingerprinting and grouping.

Lb. plantarum, Lb. paraplantarum and Lb. pentosus share very similar 16 S rRNA gene sequences; $\geq 99 \%$ and also have similar phenotypic traits making it difficult to differentiate these three species [38]. The $\operatorname{rec} A$ gene sequence was therefore considered a reliable and useful target in order to differentiate $L b$. plantarum, $L b$. pentosus and Lb. paraplantarum species [38]. In this study, the size of the amplicons of all the 10 presumptive $L b$.

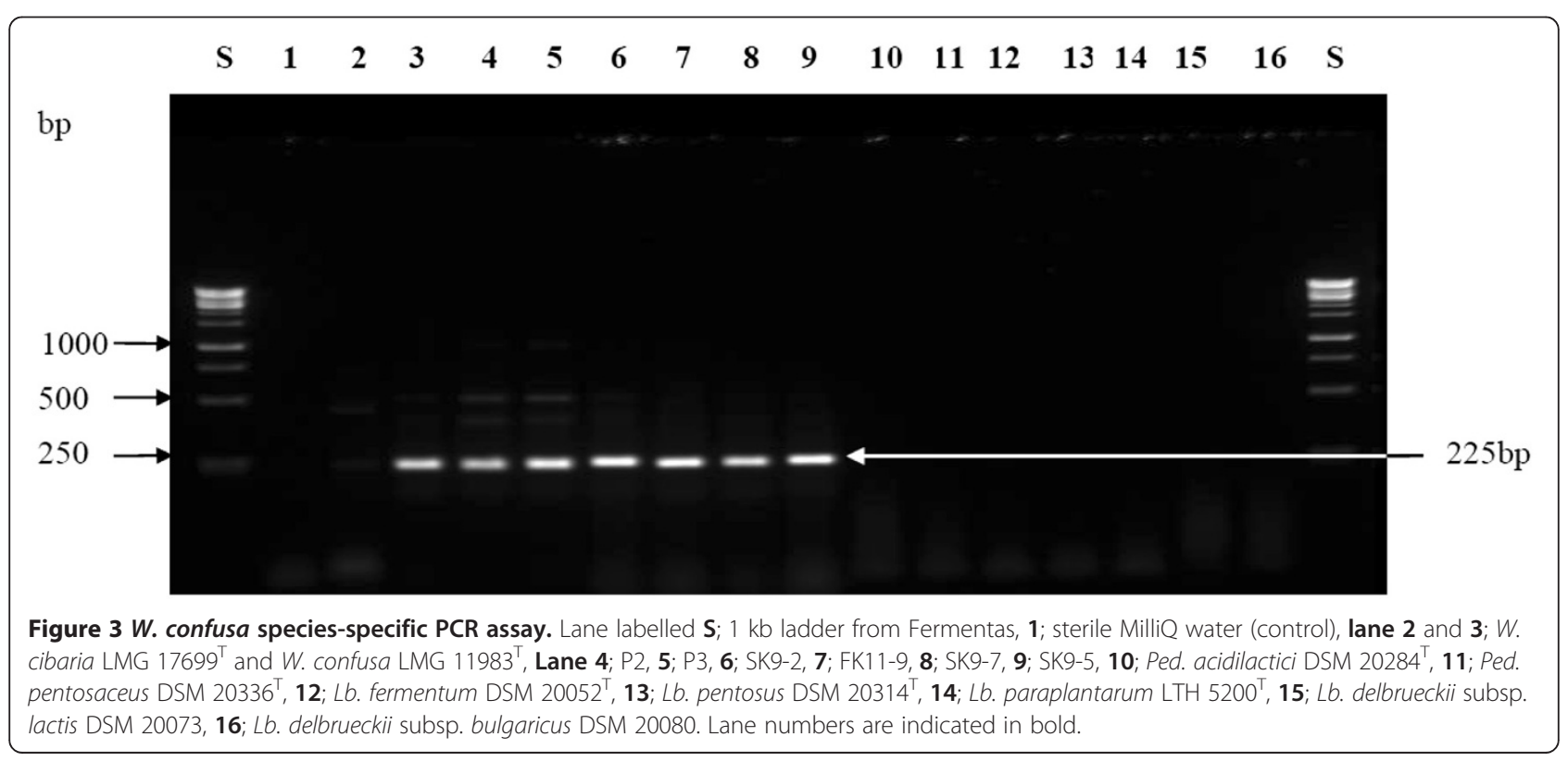


Table 2 MIC distributions of 9 antibiotics for lactic acid bacteria isolated from three different African fermented food products. Antibiotic MIC was determined by the broth microdilution method

\begin{tabular}{|c|c|c|c|c|c|c|c|c|c|c|c|c|}
\hline \multirow[t]{2}{*}{ Antibiotic } & \multirow[t]{2}{*}{ Species } & \multirow[t]{2}{*}{$\mathbf{n}$} & \multicolumn{10}{|c|}{ Number of strains with MIC (mg/L): } \\
\hline & & & 0.25 & 0.5 & 1 & 2 & 4 & 8 & 16 & 32 & 64 & 128 \\
\hline \multirow[t]{8}{*}{ AMP } & Lb. plantarum & 10 & & 10 & & & & & & & & \\
\hline & Leuc. pseudomesenteroides & 1 & & 1 & & & & & & & & \\
\hline & Lb. ghanensis & 1 & & 1 & & & & & & & & \\
\hline & Lb. fermentum & 2 & & 2 & & & & & & & & \\
\hline & Lb. salivarius & 6 & & 6 & & & & & & & & \\
\hline & Ped. acidilactici & 3 & & & 2 & 1 & & & & & & \\
\hline & W. confusa & 5 & & 5 & & & & & & & & \\
\hline & Ped. pentosaceus & 3 & & & 2 & 1 & & & & & & \\
\hline \multirow[t]{8}{*}{$\mathrm{CHL}$} & Lb. plantarum & 10 & & & & & 10 & & & & & \\
\hline & Leuc. pseudomesenteroides & 1 & & & & & 1 & & & & & \\
\hline & Lb. ghanensis & 1 & & & & & 1 & & & & & \\
\hline & Lb. fermentum & 2 & & & & & 2 & & & & & \\
\hline & Lb. salivarius & 6 & & & & 4 & 2 & & & & & \\
\hline & Ped. acidilactici & 3 & & & & 2 & & & & & & \\
\hline & W. confusa & 5 & & & & 5 & & & & & & \\
\hline & Ped. pentosaceus & 3 & & & & 3 & & & & & & \\
\hline \multirow[t]{8}{*}{ CLIN } & Lb. plantarum & 10 & & 8 & 1 & 1 & & & & & & \\
\hline & Leuc. pseudomesenteroides & 1 & & 1 & & & & & & & & \\
\hline & Lb. ghanensis & 1 & & & 1 & & & & & & & \\
\hline & Lb. fermentum & 2 & & 2 & & & & & & & & \\
\hline & Lb. salivarius & 6 & & 6 & & & & & & & & \\
\hline & Ped. acidilactici & 3 & & 3 & & & & & & & & \\
\hline & W. confusa & 5 & & 5 & & & & & & & & \\
\hline & Ped. pentosaceus & 3 & & 3 & & & & & & & & \\
\hline \multirow[t]{8}{*}{ ERY } & Lb. plantarum & 10 & 1 & 7 & 2 & & & & & & & \\
\hline & Leuc. pseudomesenteroides & 1 & & 1 & & & & & & & & \\
\hline & Lb. ghanensis & 1 & & 1 & & & & & & & & \\
\hline & Lb. fermentum & 2 & & 2 & & & & & & & & \\
\hline & Lb. salivarius & 5 & & 3 & 2 & & & & & & & \\
\hline & Ped. acidilactici & 3 & & 2 & 1 & & & & & & & \\
\hline & W. confusa & 5 & 2 & 3 & & & & & & & & \\
\hline & Ped. pentosaceus & 3 & & 2 & 1 & & & & & & & \\
\hline \multirow[t]{8}{*}{ GEN } & Lb. plantarum & 10 & & & & & & & & 7 & 3 & \\
\hline & Leuc. pseudomesenteroides & 1 & & & & & & & & & 0 & \\
\hline & Lb. ghanensis & 1 & & & & & & & & & 0 & \\
\hline & Lb. fermentum & 2 & & & & & & & 1 & 1 & & \\
\hline & Lb. salivarius & 6 & & & & & & & 2 & 4 & & \\
\hline & Ped. acidilactici & 3 & & & & & & & & & 0 & \\
\hline & W. confusa & 5 & & & & & & & 4 & 1 & & \\
\hline & Ped. pentosaceus & 3 & & & & & & & & 1 & 2 & \\
\hline \multirow[t]{4}{*}{ KAN } & Lb. plantarum & 10 & & & & & & & & & & 0 \\
\hline & Leuc pseudomesenteroides & 1 & & & & & & & & & & 0 \\
\hline & Lb. ghanensis & 1 & & & & & & & & & & 0 \\
\hline & Lb. fermentum & 2 & & & & & & & & & & 0 \\
\hline
\end{tabular}


Table 2 MIC distributions of 9 antibiotics for lactic acid bacteria isolated from three different African fermented food products. Antibiotic MIC was determined by the broth microdilution method (Continued)

\begin{tabular}{|c|c|c|c|c|c|c|c|c|}
\hline & Lb. salivarius & 6 & & & & & & 0 \\
\hline & Ped. acidilactici & 3 & & & & & & 0 \\
\hline & W. confusa & 5 & & & & & & 3 \\
\hline & W. confusa & 5 & & & & & & 3 \\
\hline & Ped. pentosaceus & 3 & & & & & & 0 \\
\hline \multirow[t]{8}{*}{ STREP } & Lb. plantarum & 10 & & & & & 2 & 5 \\
\hline & Leuc. pseudomesenteroides & 1 & & & & & & 1 \\
\hline & Lb. ghanensis & 1 & & & & & & 1 \\
\hline & Lb. fermentum & 2 & & & & & & 2 \\
\hline & Lb. salivarius & 6 & & & & & 4 & 2 \\
\hline & Ped. acidilactici & 3 & & & & & & 0 \\
\hline & W. confusa & 5 & & & & & 2 & 3 \\
\hline & Ped. pentosaceus & 3 & & & & & & 0 \\
\hline \multirow[t]{8}{*}{ TET } & Lb. plantarum & 10 & & & 2 & 8 & & \\
\hline & Leuc. pseudomesenteroides & 1 & & & 1 & & & \\
\hline & Lb. ghanensis & 1 & & & 1 & & & \\
\hline & Lb. fermentum & 2 & & 2 & & & & \\
\hline & Lb. salivarius & 6 & 6 & & & & & \\
\hline & Ped. acidilactici & 3 & & & & 1 & 2 & \\
\hline & W. confusa & 5 & 4 & 1 & & & & \\
\hline & Ped. pentosaceus & 3 & & & & 2 & 1 & \\
\hline \multirow[t]{8}{*}{ VAN } & Lb. plantarum & 10 & & & 0 & & & \\
\hline & Leuc. pseudomesenteroides & 1 & & & 0 & & & \\
\hline & Lb. ghanensis & 1 & & & 0 & & & \\
\hline & Lb. fermentum & 2 & & & 0 & & & \\
\hline & Lb. salivarius & 6 & & & 0 & & & \\
\hline & Ped. acidilactici & 3 & & & 0 & & & \\
\hline & W. confusa & 5 & & & 0 & & & \\
\hline & Ped. pentosaceus & 3 & & & 0 & & & \\
\hline
\end{tabular}

Abbreviations: AMP, Ampicillin; CHL, Chloramphenicol; CLIN, Clindamycin; ERY, Erythromycin; GEN, Gentamicin; KAN, Kanamycin; STREP, Streptomycin; TET,

Tetracycline; VAN, Vancomycin. $n$; number of strains within each species tested. MIC range tested indicated in gray.

plantarum strains investigated in this study including strain S1 and S2 corresponded with the size of the amplicon obtained for the $L b$. plantarum DSM 20174 ${ }^{\mathrm{T}}$ which was used as the reference strain and were therefore identified as such.

Similarly, unambiguous differentiation of W. confusa and $W$. cibaria strains could not be achieved based on 16S rRNA gene sequencing due to the close relatedness of the two species. However, using a species specific PCR method reported by Fuscos et al. [39], we were able to distinguish these two closely related species. DNA from all the Weissella strains generated a PCR product with a size of $225 \mathrm{bp}$ similar to that of W. confusa LMG $11983^{\mathrm{T}}$ which was used as the reference strain and no amplified product was obtained in any of the negative control strains (Ped. acidilactici DSM20284 ${ }^{\mathrm{T}}$, Ped. pentosaceus DSM20336 ${ }^{\mathrm{T}}$, Lb. fermentum DSM20052 ${ }^{\mathrm{T}}$, Lb. pentosus
DSM20314 ${ }^{\mathrm{T}}$, Lb. paraplantarum LTH5200, Lb. delbrueckii subsp. lactis DSM20073, Lb. delbrueckii subsp. bulgaricus DSM20080). The strains were therefore identified as $W$. confusa.

The reproducibility of the broth micro-dilution method used in this study for determining the antibiotics MIC values has been confirmed in previous studies and is one of National Committee for Clinical Laboratory Standards (NCCLS) recommended methods for determining antibiotic MIC values [41,46]. Our results showed that the investigated strains were resistant to high concentration of vancomycin. In a previous study, Danielsen and Wind [47] shown that Lb. plantarum/pentosus strains were resistant to higher concentrations of vancomycin (MIC $\geq 256 \mu \mathrm{g} / \mathrm{ml}$ ). Furthermore, Lb. plantarum, $L b$. rhamnosus, and $L b$. brevis strains resistant to high concentrations of vancomycin (MICs $\geq 256 \mu \mathrm{g} / \mathrm{ml}$ ) 


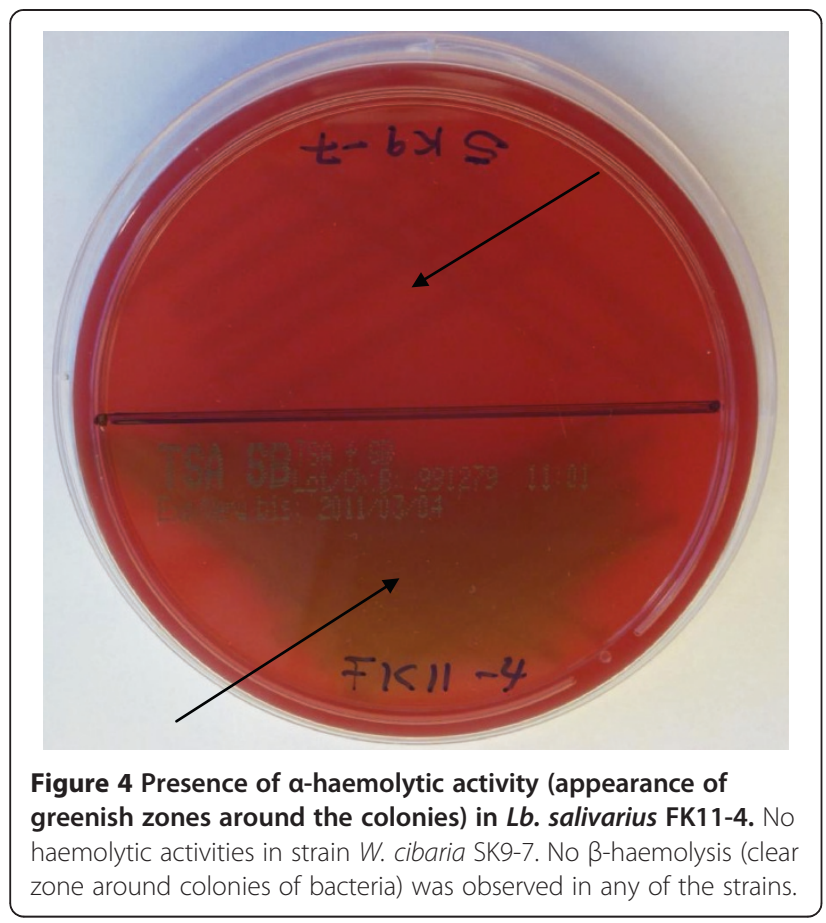

was also reported by Delgado et al. [48]. According to Ammor et al. [49], the resistance of Lactobacillus, Pediococcus and Leuconostoc species to vancomycin is due to the absence of $D$-Ala- $D$-lactate in their cell wall which is the target of vancomycin. Thus the resistance mechanisms observed among these strains is inherent or intrinsic to Lactobacillus, Leuconostoc and Pediococcus species and could therefore not be attributed to acquisition of resistance genes. The SCAN report which was adopted on 3rd July 2001 and revised on 18 April 2002 has also indicated that certain species of Lactobacillus are inherently resistant to vancomycin [35].

The bacteria were highly sensitive to erythromycin. This same observation for lactic acid bacteria was reported by others $[47,50]$. It was reported by RojoBezares et al. [50] that Lb. plantarum, Leuc. pseudomesenteroides, Ped. pentosaceus and Ped. acidilactici strains were highly sensitive to erythromycin which is in agreement with our findings.

In this study, it was observed that the majority of the bacteria (24 out of 31 strains) were resistant to gentamicin (MIC $>16 \mathrm{mg} / \mathrm{L}$ ). Ouoba et al. [34] reported a gentamicin MIC value $16-32 \mathrm{mg} / \mathrm{L}$ for $\mathrm{Lb}$. fermentum strains which is in agreement with our findings. Contrarily, the gentamicin MIC values $(16 \& 32 \mathrm{mg} / \mathrm{L})$ observed for $W$. confusa strains were higher than those reported by Ouoba et al. [34]. Comparatively, our strains showed lower gentamicin MIC values when compared to strains of European origin reported [34,47,50].

The bacteria were all susceptible to ampicillin, chloramphenicol, clindamycin, tetracycline and erythromycin (except Pediococcus) and had MIC values not above the respective recommended breakpoint values for the individual species by the Panel on Additives and Products or substances used in Animal Feed (FEEDAP) [22]. However, the MIC values obtained for gentamicin, kanamycin, vancomycin and streptomycin for some of the strains were higher than the recommended FEEDAP Panel's breakpoint values and were therefore considered resistant to these antibiotics and may require further molecular investigation to ascertain the cause of these resistance patterns.

Microbial strains with $\beta$-haemolytic activity unlike $\alpha$ haemolytic activity produce exotoxin such as streptolysin S (SLS) which lysis blood cells and thereby affects the immune system. On blood agar plates, the blood lysis results in clearing around colonies. The general presence of poor haemolytic activities among LAB is an indication of their safety properties and is among other characteristics that accorded LAB the GRAS status. As was also observed in this study, there was generally low presence of haemolytic activity or production of streptolysin among the bacteria investigated. Only 9 out of 33 strains exhibited $\alpha$-haemolytic activity and no strains showed $\beta$ haemolytic activity. It was reported by Hussain et al. [51] that out of a total of 535 enterococcal isolates, only 18 strains demonstrated haemolysis on blood agar of which 12 strains showed $\beta$-haemolysis and the remaining 6 strains showed $\alpha$-haemolysis. Ulymaz et al. [52] also reported that Ped. pentosaceus BH105 isolated from human faeces showed no haemolytic activity on blood agar. In this study, the absence of $\beta$-haemolysis in any of the strains is a good indication of low prevalence of pathogenicity among the isolates.

\section{Conclusions}

A total of $33 \mathrm{LAB}$ from three different indigenous African food products were characterised by genotypic techniques. The molecular techniques used in this study have proved successful in the identifications of the strains to species and subspecies level. The identity of some of the isolates such as Lb. fermentum ZN7b-2 and ZN7b-7, Weissella confusa strains and Lb. plantarum S1 and S2 were re-established and the identity of the remaining strains confirmed.

The isolates were susceptible to ampicillin, chloramphenicol, clindamycin and erythromycin but resistant to kanamycin, streptomycin and vancomycin which is more probably an intrinsic feature of LAB since similar observations were reported elsewhere. Variable and multiple resistance to tetracycline and gentamicin was observed in some strains. No $\beta$-haemolysis was observed in any of the strains; however, 27\% (9 strains) exhibited $\alpha$ haemolytic activity. Based on the outcome of this study, it can be concluded that the resistance of Lactobacillus 
spp. to kanamycin and vancomycin indicate the prevalence of this intrinsic property among Lactobacillus spp. globally and thus strains of African origin do not possess any higher risk in terms of their antibiotic resistance profiles and haemolytic activities as compared to isolates of other geographical areas. Thus, the use of strains from African fermented food could be interesting as candidates of new future commercial starter cultures for selected product groups or probiotics.

\section{Acknowledgements}

The funding provided by DANIDA and Chr. Hansen A/S, Denmark, under the Danish Government PPP (Public Private Partnership) initiative for David Bichala Adimpong is very much appreciated. We will also like to thank Dr. Birgitte Stuer-Lauridsen (Chr-Hansen, A/S, Denmark) for her careful reading of this manuscript.

\section{Authors' contribution}

DBA participated in project conception and carried out most of the experiments, analysed and interpreted the data and wrote the manuscript DSN and $L J$ designed and supervised the analysis and results interpretation on molecular characterization and corrected the manuscript. KIS and PMFD conceived the study participated in the design and supervised the work on antibiotics susceptibility profiles and haemolytic activity. All authors read and approved the final version of the manuscript.

Received: 15 September 2011 Accepted: 17 May 2012

Published: 17 May 2012

\section{References}

1. Amoa-Awua WKA, Jakobsen M: The role of Bacillus species in the fermentation of cassava. J App/ Bacteriol 1996, 79:250-256.

2. Jepersen L: Occurrence and taxonomic characteristics of strains of Saccharomyces cerevisiae predominant in African indigenous fermented foods and beverages. FEMS Yeast Res 2003, 3:191-200.

3. Parkouda C, Nielsen DS, Azokpota P, Ouoba LII, Amoa-Awua WK, Thorsen L, Hounhouigan JD, Jensen JS, Tano-Debrah K, Diawara B, Jakobsen M: The microbiology of alkaline-fermentation of indigenous seeds used as food condiments in Africa and Asia. Crit Rev Microbiol 2009, 35:139-156.

4. Dakwa S, Sakyi-Dawson E, Diako C, Annan NT, Amoa-Awua WK: Effect of boiling and roasting on the fermentation of soybeans into dawadawa (soy-dawadawa). Int J Food Microbiol 2005, 104:69-82.

5. Beukes EM, Bester BH, Mostert JF: The microbiology of South African traditional fermented milks. Int J Food Microbiol 2001, 63:189-197.

6. Sefa-Dedeh S, Cornelius B, Amoa-Awua W, Sakyi-Dawson E, Afoakwa EO: The microflora of fermented nixtamalized corn. Int J Food Microbiol 2004, 96:97-102.

7. Obilie EM, Tano-Debrah K, Amoa-Awua WK: Souring and breakdown of cyanogenic glucosides during the processing of cassava into akyeke. Int J Food Microbiol 2004, 93:115-121.

8. Nielsen DS, Teniola OD, Ban-Koffi L, Owusu M, Andersson TS, Holzapfel WH: The microbiology of Ghanaian cocoa fermentations analysed using culture-dependent and culture-independent methods. Int J Food Microbiol 2007, 114:168-186.

9. Sawadogo-Lingani H, Lei V, Diawara B, Nielsen DS, Moller PL, Traore AS, Jakobsen M: The biodiversity of predominant lactic acid bacteria in dolo and pito wort for the production of sorghum beer. J Appl Microbio/ 2006 103:765-777.

10. Kostinek M, Specht I, Edward VA, Pinto C, Egounlety M, Sossa C: Characterisation and biochemical properties of predominant lactic acid bacteria from fermenting cassava for selection as starter cultures. Int $J$ Food Microbiol 2007, 114:342-351

11. Obodai M, Dodd CER: Characterization of dorminant microbiota of a Ghanaian feremented milk product, nyarmie, by culture-and nonculturebased methods. J App/ Microbiol 2006, 100:1355-1363.

12. Abdelgadir WS, Hamad SH, Moller PL, Jakobsen M: Characterization of the dominant microbiota of Sudanese fermented milk Rob. Int Dairy J 2001, 11:63-70.
13. Holzapfel W: Use of starter cultures in fermentation on a household scale. Food Cont 1997, 8:241-258.

14. Lei $\mathrm{V}$, Jakobsen M: Microbiological characterization and probiotic potential of koko and koko sour water, African spontaneously fermented millet porridge and drink. J Appl Microbiol 2004, 96:384-397.

15. Padonou SW, Nielsen DS, Hounhouigan JD, Thorsen L, Nago MC, Jakobsen $\mathrm{M}$ : The microbiota of Lafun, an african traditional cassava food product. Int J Food Microbiol 2009, 133:22-30.

16. Amoa-Awua WK, Appoh FE, Jakobsen M: Lactic acid fermentation of cassava dough into agbelima. Int J Food Microbiol 1996, 31:87-98.

17. Ouoba LII, Diawara B, Amoa-Awua WK, Traorq AS, Moller PL: Genotyping of starter cultures of Bacillus subtilis and Bacillus pumilus for fermentation of African locust bean (Parkia biglobosa) to produce Soumbala. Int J Food Microbiol 2004, 90:197-205

18. Glover RL, Abaidoo RC, Jakobsen M, Jespersen L: Biodiversity of Saccharomyces cerevisiae isolated from a survey of pito production sites in various parts of Ghana. Syst Appl Microbiol 2005, 28(8):755-761.

19. Papalexandratou Z, Camu N, Falony G, De Vuyst L: Comparison of the bacterial species diversity of spontaneous cocoa bean fermentations carried out at selected farms in Ivory Coast and Brazil. Food Microbiol 2011, 5:964-973.

20. Adams MR: Safety of industrial lactic acid bacteria. J Biotechnol 1999, 68:171-178.

21. Adams MR, Marteau P: On the safety of lactic acid bacteria from food. Int J Food Microbiol 1995, 27:263-264.

22. FEEDAP Panel: opinion of the scientific panel on additives and products or substances used in animal feed on the updating of the criteria used in assessment of bacterial resistance to antibiotics of human and veterinary importance. EFSA J 2008, 732:1-15.

23. Mathur S, Singh R: Antibiotic resistance in food lactic acid bacteria: a review. Int J Food Microbiol 2005, 105:281-295.

24. Temmermana R, Pot B, Huys G, Swings J: Identification and antibiotic susceptibility of bacterial isolates from probiotic products. Int J Food Microbiol 2003, 81:1-10.

25. Kastner S, Perreten V, Bleuler H, Hugenschmidt G, Lacroix C, Meile L: Antibiotic susceptibility patterns and resistance genes of starter cultures and probiotic bacteria used in food. Syst Appl Microbiol 2006, 29:145-155.

26. Gevers D, Danielsen M, Huys G, Swings J: Molecular characterization of tet (M) genes in Lactobacillus isolates from different types of fermented dry sausage. Appl Environ Microbiol 2003, 69:1270-1275.

27. Danielsen M, Seifert J: The development of international ISO/IDF standard for susceptibility testing of lactic acid bacterial and bifidobacteria based on the contributions from PROSAFE and ACE-ART. Int J Prob Prob 2008 $3: 247-248$

28. Flórez AB, Tosi L, Danielsen M, von Wright A, Bardowski J, Morelli L, Mayo B Resitance-susceptibility profiles of Lactococcus lactic and Streptococcus thermophilus strains to eight antibiotics and proposition of new cut-offs. Int J Prob 2008, 3:249-256.

29. Korhonen JM, Danielsen M, Mayo B, Egervärn M, Axelsson L, Huys G, von Wright A: Antimicrobial susceptibility and proposed microbiological cut-off values of Lactobacilli by phenotypic determination. Int J Prob 2008, 3:257-268.

30. Helegbe GK, Anyidoho LY, Gyang FN: Screening of the efficacy of some commonly used antibiotics in Ghana. Res J Microbiol 2009, 4:214-221.

31. Tagoe DNA, Attah CO: A Study of antibiotic use and abuse in Ghana: a case study of the Cape Coast metropolis. IJH 2010, 11:2. Number.

32. Kunin CM: The resistance to antimicrobial drugs: a worldwide calamity. Ann Intern Med 1993, 118:557-561.

33. Newman MJ, Frimpong E, Asamoah-Adu A, Sampane-Donkor E: Resistance to antimicrbial drugs in Ghana. In The Ghanaian-Dutch collaboration for health research and development: project number 2001/GD/07, Technical Report Series, Volume 5. 2006.

34. Ouoba LII, Lei $V$, Jensen LB: Resistance of potential probiotic lactic acid bacteria and bifidobacteria of African and European origin to antimicrobials: Determination and transferability of the resistance genes to other bacteria. Int J Food Microbiol 2008, 121:217-224.

35. Opinion of the Scientific Committee on Animal Nutrition on the criteria for assessing the safety of microorganism resistant to antibiotics of human clinical and veterinary importance. Adopted on 3 July 2001, revised on 18 April 2002.

36. Satokari RM, Vaughan EE, Akkermans-van Vliet WM, Saarela M, de Vos WM: Bifidobacterial diversity in human feces detected by genus-specific PCR and denaturing gradient gel electrophoresis. Appl Environ Microbio/ 2001 67:504-513. 
37. Altschul SF, Madden TL, Schaffer AA, Zhang Z, Miller W, Lipman DJ: Gapped BLAST and PSI-BLAST: a new generation protein database search programs. Nucl Acids Res 1997, 25:3389-3402.

38. Torriani S, Felis EG, Dellaglio F: Differentiation of Lactobacillus plantarum, L. pentosus, and $L$. paraplantarum by recA gene sequence analysis and multiple PCR assay with recA gene-derived primers. Appl Environ Microbiol 2001, 67:3450-3454.

39. Fusco V, Quero GM, Stea G, Morea M, Visconti A: Novel PCR-based identification of Weissella confusa using an AFLP-derived marker. Int 」 Food Microbiol 2011, 145:437-443.

40. Mayrhofer S, Domig K, Amtmann E, Van Hoeck AHAM, Petersson A, Mair C, Mayer HK, Kneifel W: Antibiotic susceptibility of Bifidobacterium thermophilum and Bifidobacterium pseudolongum isolates from animal sources. J Food Prot 2007, 70:119-124.

41. Domig KJ, Mayrhofer S, Zitz U, Mair C, Petersson A, Amtmann E, Mayer HK, Kneifel W: Antibiotic susceptibility testing of Bifidobacterium thermophilum and Bifidobacterium pseudolongum strains: Broth microdilution vs. agar disc diffusion assay. Int J Food Microbiol 2007, 120:191-195.

42. Harrigan WF: Laboratory methods in food microbiology. Academic Press: New York; 1998.

43. Gevers D, Huys G, Swigs J: Applicability of rep-PCR fingerprinting for identification of Lactobacillus species. FEMS Microbiol Lett 2001, 205:31-36.

44. De Vuyst L, Camu N, De Winter T, Vandemeulebroecke K, Van de Perre V, Vancanneyt M, De Vos P, Cleenwerck I: Validation of the (GTG)(5)-rep-PCR fingerprinting technique for rapid classification and identification of acetic acid bacteria, with a focus on isolates from Ghanaian fermented cocoa beans. Int J Food Microbiol 2008, 125:79-90.

45. Svec P, Vancanneyt M, Seman M, Snauwaert C, Lefebvre K, Sedlácek I, Swings J: Evaluation of (GTG)5-PCR for identification of Enterococcus spp. FEMS Microbiol Lett 2005, 247:59-63.

46. Wallmann J, Böttner A, Goossens L, Hafez HM, Hartmann K, Kaspar H: Results of an interlaboratory test on antimicrobial susceptibility testing of bacteria from animals by broth microdilution. Int J Antimicrob Agents 2006, 27:482-490.

47. Danielsen M, Wind A: Susceptibility of Lactobacillus spp. to antimicrobial agents. Int J Food Microbiol 2003, 82:1-11.

48. Delgado $S$, Flórez $A B$, Mayo B: Antibiotic susceptibility of Lactobacillus and Bifidobacterium species from the human gastrointestinal tract. Curr Microbiol 2005, 50:202-207.

49. Ammor MS, Flérez AB, Mayo B: Antibiotic resistance in non-enterococcal lactic acid bacteria and bifidobacteria. Food Microbiol 2007, 24:559-570.

50. Rojo-Bezares B, Sbenz Y, Poeta P, Zarazaga M, Ruiz-Larrea F, Torres C: Assessment of antibiotic susceptibility within lactic acid bacteria strains isolated from wine. Int J Food Microbiol 2006, 111:234-240.

51. Hussain M, Khan MT, Wajid A, Rasool SA: Technological characterization of indigenous enterococcal population for probiotic potential. Pak J Bot 2008, 40:867-875.

52. Uymaz B, Símşek Ö, Akkoc N, Ataoğlu H, Akcelik M: In vitro characterization of probiotic properties of Pediococcus pentosaceus $\mathrm{BH} 105$ isolated from human faeces. Ann Microbiol 2009, 59:485-491.

\section{Submit your next manuscript to BioMed Central and take full advantage of:}

- Convenient online submission

- Thorough peer review

- No space constraints or color figure charges

- Immediate publication on acceptance

- Inclusion in PubMed, CAS, Scopus and Google Scholar

- Research which is freely available for redistribution 